\title{
Rate-Dependent Distal Renal Tubular Acidosis and Carnitine Palmitoyltransferase I Deficiency
}

\author{
A. J. I. W. BERGMAN, R. A. M. G. DONCKERWOLCKE, M. DURAN, \\ J. A. M. SMEITINK, B. MOUSSON, C. VIANEY-SABAN, AND B. T. POLL-THE \\ Department of Metabolic Diseases [A.J.I.W.B., M.D., J.A.M.S., B.T.P.-T.] and Department of \\ Nephrology [R.A.M.G.D.], University Children's Hospital "Het Wilhelmina Kinderziekenhuis," \\ 3512 LK Utrecht, The Netherlands, and Unité d'Etude des Maladies Métabolic, Hôpital \\ Debrousse, F-69437 Lyon Cédex 03, France [B.M., C.V.-S.]
}

\section{ABSTRACT}

An infant girl presented with recurrent episodes of Reye-like syndrome associated with hypoketosis and plasma carnitine levels in the high-normal range. A liver biopsy revealed massive macrovesicular steatosis. Ketogenesis was absent after a long-chain triglyceride loading test; in contrast, the medium-chain triglyceride loading test resulted in a brisk rise in plasma ketone concentration. Carnitine palmitoyltransferase I deficiency was demonstrated in cultured skin fibroblasts. Hypoglycemia was only found once in the neonatal period. Renal carnitine handling was normal except for a higher renal threshold for free carnitine. Mild, persistent metabolic acidosis was a constant feature, even during periods between metabolic decompensation. Evaluation of the renal acidification capacity showed a failure to acidify the urine during spontaneous acidosis but increased acid excretion and a normal decrease of urinary $\mathrm{pH}$ after acid loading. Also, a small difference between urine and blood $\mathrm{PCO}_{2}$ was found after bicarbonate administration. This acidification defect can best be explained as an abnormality in distal tubular $\mathrm{H}^{+}$ secretion: a rate-dependent distal tubular acidosis. It is speculated that long-chain acylcarnitines, substances that cannot be formed by carnitine palmitoyltransferase I-deficient patients, play an essential role in renal acid-base homeostasis. (Pediatr Res 36: 582-588, 1994)

\section{Abbreviations}

CPT, carnitine palmitoyltransferase

LCT, long-chain triglyceride

MCT, medium-chain triglyceride

RTA, renal tubular acidosis

dRTA, distal renal tubular acidosis

(U-B) $\mathrm{PCO}_{2}$, difference between urine and blood carbon

dioxide pressure
Mitochondrial fatty acid oxidation disorders are increasingly being recognized as an important group of inborn errors of metabolism that can cause energy deprivation at times of stress, prolonged fasting, or exercise. Thus far, 13 different enzyme defects have been identified. The presenting symptoms are highly variable and the clinical and biochemical characteristics only rarely permit a specific diagnosis in the absence of a direct enzyme analysis method.

For the transport of long-chain fatty acids across the mitochondrial membrane, before they undergo $\beta$-oxidation in the mitochondrial matrix, carnitine palmitoyltransferases (CPT I and CPT II) and the carnitineacylcarnitine translocase are required. CPT I, located on the inner side of the outer mitochondrial membrane, catalyzes the formation of fatty acylcarnitines from acyl-

Received December 28, 1993; accepted May 26, 1994.

Correspondence and reprint requests: B. T. Poll-The, M.D., Ph.D., University Children's Hospital "Het Wilhelmina Kinderziekenhuis," Nieuwe Gracht 137 3512 LK Utrecht, The Netherlands.
CoA and carnitine (1). Acylcarnitine is transferred across the inner mitochondrial membrane in exchange for carnitine by carnitine acyl-carnitine translocase (2). Longchain acyl-CoA esters are generated inside the mitochondrion by the action of CPT II.

Patients with CPT I deficiency suffer from recurrent episodes of hypoketotic hypoglycemia characterized by decreased levels of consciousness, hepatomegaly, and hepatic dysfunction. Usually the patients are symptom free when their mitochondrial fatty acid oxidation system is not stressed.

CPT I deficiency was first described in 1981 (3) in a patient with severe hypoketotic hypoglycemia without dicarboxylic aciduria. Since then, only nine patients have been reported in the literature (4-11). More recently, Falik-Borenstein et al. (10) described a patient with a CPT I deficiency and RTA. In this report, we describe a girl with CPT I deficiency in whom the disease was characterized by multiple episodes of Reye-like syndrome, normal or slightly increased plasma carnitine con- 
centrations, and persistent mild metabolic acidosis. Extensive renal function tests showed a distal tubular $\mathrm{H}^{+}$ transport defect, which stresses the necessity of renal evaluation in the workup of patients with CPT I deficiency.

\section{CASE REPORT}

A girl was born to unrelated, healthy Dutch parents after a normal pregnancy and delivery. Birth weight was $3530 \mathrm{~g}$. After 2 uneventful days, vomiting, increasing lethargy, transient cardiac arrhythmia, and a respiratory arrest developed, requiring mechanical ventilatory support for $2 \mathrm{~d}$. Antibiotics were given for suspected septicemia. At that time, the following blood laboratory values were recorded: glucose $1.6 \mathrm{mmol} / \mathrm{L}$ (normal 2.8-5.6 $\mathrm{mmol} / \mathrm{L}$ ), capillary $\mathrm{pH} 7.33, \mathrm{PCO}_{2} 50 \mathrm{~mm} \mathrm{Hg}$, base excess $-0.4 \mathrm{mmol} / \mathrm{L}, \mathrm{Po}_{2} 49 \mathrm{~mm} \mathrm{Hg}$, alanine aminotransferase $78 \mathrm{U} / \mathrm{L}$ (normal 3-47 U/L), aspartate aminotransferase $105 \mathrm{U} / \mathrm{L}$ (normal 7-43 U/L), sodium ions $139 \mathrm{mmol} / \mathrm{L}$ (normal 135-148 $\mathrm{mmol} / \mathrm{L}$ ), and potassium ions 7.3 $\mathrm{mmol} / \mathrm{L}$ (normal 4.1-5.3 mmol/L). All bacterial and viral cultures remained negative. A complete recovery was obtained after $9 \mathrm{~d}$ of symptomatic therapy, and no explanation for the high potassium was found. A cardiac ultrasound examination showed no abnormalities.

Between the age of 6 mo and $3 y$, the patient presented nine episodes of a Reye-like syndrome, often preceded by a mild upper respiratory tract infection. These episodes were marked by lethargy, hepatomegaly, and the following laboratory data: blood ammonia $52-145 \mu \mathrm{mol} / \mathrm{L}$ (normal 55-90 $\mu \mathrm{mol} / \mathrm{L}$ ), aspartate aminotransferase 20 $600 \mathrm{U} / \mathrm{L}$, alanine aminotransferase $25-600 \mathrm{U} / \mathrm{L}$, capillary pH 7.27-7.37, and base excess -3.0-0.1. Hypoglycemia was never detected. A liver biopsy at the age of $10 \mathrm{mo}$ revealed massive macrovesicular and microvesicular steatosis with a normal amount of glycogen. The urinary excretion of dicarboxylic acids was slightly increased during one episode (3-OH-butyric acid $40 \mu \mathrm{mol} / \mathrm{L}$, adipic acid $221 \mu \mathrm{mol} / \mathrm{L}, 3-\mathrm{OH}$-adipic acid $415 \mu \mathrm{mol} / \mathrm{L}$, unsaturated suberic acid $116 \mu \mathrm{mol} / \mathrm{L}$, suberic acid $123 \mu \mathrm{mol} / \mathrm{L}$, sebacic acid $373 \mu \mathrm{mol} / \mathrm{L}, 3-\mathrm{OH}$-sebacic acid $252 \mu \mathrm{mol} / \mathrm{L}$, dodecanedioic acid $300 \mu \mathrm{mol} / \mathrm{L}$, and 3-OH-dodecanedioic acid $66 \mu \mathrm{mol} / \mathrm{L}$ ). Plasma concentrations of free carnitine were within the normal range or moderately increased on several occasions $(51,58,59$, and $63 \mu \mathrm{mol} / \mathrm{L}$ at 2 and $3 \mathrm{y}$; normal values $47 \pm 7.0 \mu \mathrm{mol} / \mathrm{L}$ ). At each episode, there was a rapid improvement of the lethargy upon the administration of parenteral glucose, and the transaminases returned to normal within 2 to $4 \mathrm{wk}$ depending on the severity of the decompensation.

An LCT loading test performed at the age of $18 \mathrm{mo}$ showed no increase of the plasma ketones, in contrast to the brisk rise in plasma ketones during the MCT loading test. After the latter test, the patient was put on an MCT-enriched diet, and the parents were instructed to prevent a fasting period longer than $12 \mathrm{~h}$. As a result of this regimen, the frequency of hospitalization became less during episodes of vomiting associated with a mild infection. Although her plasma glucose was never below $3 \mathrm{mmol} / \mathrm{L}$, she always recovered quickly after i.v. infusion of glucose.

At the age of $3 \mathrm{y}$, her mental and motor development were normal. Her length was $95 \mathrm{~cm}$ (50th percentile), weight $13.6 \mathrm{~kg}$ (30th percentile), and head circumference $48 \mathrm{~cm}$ (50th percentile). Between the acute episodes, her liver was normal in size and function. However, a mild persistent metabolic acidosis was noted. The patient required daily oral supplementation of $4 \mathrm{mmol}$ of sodium bicarbonate per $\mathrm{kg}$ to maintain serum bicarbonate concentrations between 19 and $21 \mathrm{mmol} / \mathrm{L}$.

Renal function tests were performed at the age of $3 y$, after parental informed consent for studies had been obtained.

\section{METHODS}

\section{Metabolic Investigations}

LCT and MCT loading tests were performed to test the long-chain and medium-chain fatty acid oxidation in vivo. After a 10-h overnight fast, LCT (sunflower oil; $1.5 \mathrm{~g} / \mathrm{kg}$ ) or MCT $(1.5 \mathrm{~g} / \mathrm{kg})$ were administered orally. The plasma concentrations of glucose, FFA, $\beta$-hydroxybutyrate, and acetoacetate were determined at $0,1,2$, and $3 \mathrm{~h}$ after the load by routine clinical chemical methods.

Organic acids in plasma (12) and urine (13) were determined by gas chromatography/mass spectrometry. Total and free plasma and urinary carnitine were measured by a spectrophotometric method using dithio-bis-nitrobenzoic acid (14). Plasma was deproteinized using Amicon CF50 Centriflo ultrafiltration membrane cones (Amicon Corp., Danvers, MA).

Studies of ${ }^{14} \mathrm{C}$-labeled fatty acid oxidation were performed in intact cultured skin fibroblasts as previously described (8). The activities of mitochondrial long-chain, medium-chain, and short-chain acyl-CoA dehydrogenases were measured in fibroblasts using the electrontransferring flavoprotein reduction assay (15). The CPT I and CPT II activities were determined in fibroblasts as previously described $(5,8)$.

\section{Renal Investigations}

Renal function tests were performed over a 2-d period, after cessation of the bicarbonate supplementation for 3 d. Two needles were placed into peripheral veins, one for the infusion of the test substances and one for the repeated blood sampling. Urine was collected by an indwelling urinary catheter.

The glomerular filtration rate was determined during continuous infusion of inulin and timed collections of urine and plasma samples by following standard methods (16). Inulin was measured by the anthrone method (16). Simultaneously, the clearance of endogenous (free and acyl) carnitine was measured. 
Acid challenge test. Urinary acidification and acid excretion were assessed after i.v. administration of arginine hydrochloride $\left(150 \mathrm{mmol} / \mathrm{m}^{2}\right.$ body surface area as a $10 \%$ solution) as described by Loney et al. (17). Blood samples were analyzed for inulin, $\mathrm{pH}$, and bicarbonate concentration, and urine samples for volume, $\mathrm{pH}$, titratable acid, $\mathrm{NH}_{4}{ }^{+}$, and inulin. After arginine hydrochloride administration, acidosis was corrected by overnight administration of $30 \mathrm{mmol}$ of sodium bicarbonate i.v.

Bicarbonate loading. The following morning, $20 \mathrm{mmol}$ of sodium bicarbonate was infused in $1 \mathrm{~h}$ to obtain maximal alkalinized urine. During this period and during the following hour, urine samples were collected in 30-min periods, and capillary blood samples were obtained at 1 and $2 \mathrm{~h}$ after the start of the sodium bicarbonate infusion. In all urine and blood samples, $\mathrm{pH}, \mathrm{PCO}_{2}$, creatinine, and bicarbonate concentration were determined; urine volumes were also measured.

Distal tubular hydrogen ion secretion was assessed by calculation of the (U-B) $\mathrm{PCO}_{2}$ after maximal alkalinization of the urine was obtained. Simultaneous measurements of the clearance of creatinine and bicarbonate allowed calculation of tubular reabsorption and fractional excretion of bicarbonate.

Renal handling of carnitine was assessed as described by Engel et al. (18). After an overnight fast, hydration was provided by oral administration of $15 \mathrm{~mL}$ of water per $\mathrm{kg}$. After a bolus injection of inulin of $50 \mathrm{mg} / \mathrm{kg}$, infusion of $25 \mathrm{mg} \cdot \mathrm{m}^{-2} \cdot \mathrm{min}^{-1}$ was continued for $250 \mathrm{~min}$. Forty-five min after the start of the inulin infusion, $\mathrm{L}$-carnitine was infused at a constant rate of $0.25 \mu \mathrm{mol} / \mathrm{min} / \mathrm{kg}$ for $205 \mathrm{~min}$. Urine samples were collected at 30-min intervals, and plasma samples were obtained at the midpoint of each urine collection for determination of total and free carnitine and inulin. Rates of filtration and excretion of carnitine are expressed as $\mu \mathrm{mol} / 100 \mathrm{~mL}$ glomerular filtrate. Reabsorption of carnitine was calculated from the difference between filtration and excretion. The fractional excretion of filtered carnitine was calculated by the following formula: $U_{\text {carnitine }} \times$ $P_{\text {inulin }} / P_{\text {carnitine }} \times U_{\text {inulin }} \times 100$, where $U$ is urine and $P$ is plasma.

\section{RESULTS}

\section{Metabolic Investigations}

The plasma total carnitine was in the high-normal range (mean $61 \mu \mathrm{mol} / \mathrm{L}$; control $<65 \mu \mathrm{mol} / \mathrm{L}$ ).

The urinary excretion of dicarboxylic acids was slightly increased during one episode of decompensation; the profile was dominated by dodecanedioate $(300 \mu \mathrm{mol} /$ L). Plasma organic acid analysis did not reveal the presence of unusual substances such as decenoic acid or 3-hydroxy-fatty acids.

The response of total plasma ketone bodies during in vivo loading with LCT or MCT is shown in Figure 1. Values of plasma ketone bodies remained inappropriately low after the LCT loading ( $\beta$-hydroxybutyrate 0.096

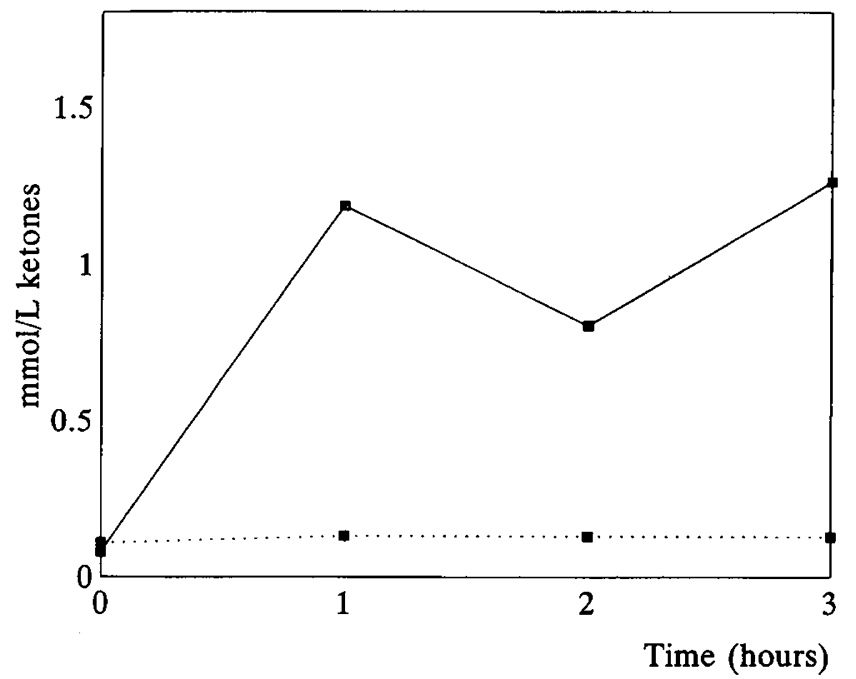

Figure 1. Plasma 3-hydroxybutyrate plus acetoacetate after administration of LCT $(1.5 \mathrm{~g} / \mathrm{kg})$ or MCT $(1.5 \mathrm{~g} / \mathrm{kg})$ in the patient. There is no rise in the sum of ketone bodies (3-hydroxybutyrate and acetoacetate) after LCT loading (dotted line) compared with the rapid rise of ketone bodies after MCT loading (solid line).

$\mathrm{mmol} / \mathrm{L}$, acetoacetate $0.038 \mathrm{mmol} / \mathrm{L}$ ), indicating a defect in the hepatic long-chain fatty acid oxidation. In contrast, plasma ketones rose rapidly ( $\beta$-hydroxybutyrate from 0.056 to $0.802 \mathrm{mmol} / \mathrm{L}$ and acetoacetate from 0.023 to $0.463 \mathrm{mmol} / \mathrm{L}$ ) after the MCT loading. The blood glucose levels as well as the urinary organic acids remained normal throughout both loading tests. The activity of CPT I in the patient's skin fibroblasts was significantly decreased (17\% of mean control values; Table 1); CPT II activity was normal. Both medium-chain and short-chain fatty acids were oxidized normally, whereas the rate of long-chain fatty acid oxidation in the patient's fibroblasts was very low compared with that of control subjects (Table 1). Activities of long-chain, medium-chain, and short-chain acyl-CoA dehydrogenases were normal (data not shown).

Table 1. CPT activity in homogenate of cultured fibroblasts and oxidation of ${ }^{14} \mathrm{C}$-labeled fatty acids in cultured fibroblasts

\begin{tabular}{lcc}
\hline & \multicolumn{2}{c}{ CPT activity in cultured fibroblasts* } \\
\cline { 2 - 3 } & Patient & Controls $\dagger(n=20)$ \\
\hline CPT I & 0.18 & $1.04 \pm 0.20$ \\
CPT I + malonyl CoA & 0.13 & $0.18 \pm 0.10$ \\
CPT II & 3.18 & $2.08 \pm 0.41$ \\
& & Fatty acid oxidation $\ddagger$ \\
\cline { 2 - 3 } & & Simultaneous controls $\dagger$ \\
& & $(n=5)$ \\
\hline$\left[1-{ }^{14} \mathrm{C}\right]$ palmitate & & $1.18 \pm 0.29(0.80-1.52)$ \\
${ }^{14} \mathrm{CO}{ }_{2}$ & 0.11 & $1.61 \pm 0.12(1.47-1.70)$ \\
PCA-soluble compounds $\S$ & 0.43 & $1.62 \pm 0.49(1.05-2.25)$ \\
{$\left[1-{ }^{14} \mathrm{C}\right]$ octanoate $\left({ }^{14} \mathrm{CO}_{2}\right)$} & 2.69 & $2.70 \pm 0.32(2.17-2.99)$ \\
{$\left[1,4-{ }^{14} \mathrm{C}\right]$ succinate $\left({ }^{14} \mathrm{CO}_{2}\right)$} & 2.92 & \\
\hline
\end{tabular}

${ }^{*}$ nmol palmitoylcarnitine produced $\cdot \mathrm{min}^{-1} \cdot(\mathrm{mg} \text { protein })^{-1}$.

$\dagger$ Mean \pm SD (range).

$\ddagger$ nmol fatty acid or succinate oxidized $\cdot h^{-1} \cdot\left(10^{6} \text { cells }\right)^{-1}$.

$\S$ PCA, perchloric acid. 


\section{Renal Investigations}

The glomerular filtration rate was within the normal range $\left(106 \mathrm{~mL} / \mathrm{min} / 1.73 \mathrm{~m}^{2}\right.$; range $\left.100-115 \mathrm{~mL} / \mathrm{min} / 1.73 \mathrm{~m}^{2}\right)$.

Acid challenge test. After the discontinuation of the sodium bicarbonate supplementation, the patient developed a spontaneous acidosis ( $\mathrm{pH}$ 7.31). During acidosis, urinary $\mathrm{pH}$ remained relatively high (6.8). Acidosis persisted despite quantitative important ammonium excretion $\left(81 \mu \mathrm{Eq} / \mathrm{min} / 1.73 \mathrm{~m}^{2}\right)$ as shown in Table 2. After loading with arginine hydrochloride, the urinary $\mathrm{pH}$ decreased to 4.7 with an increased acid excretion (179 $\mu \mathrm{Eq} / \mathrm{min} / 1.73 \mathrm{~m}^{2}$ ). The titratable acid was 70 and the $\mathrm{NH}_{4^{+}}$was $108 \mu \mathrm{Eq} / \mathrm{min} / 1.73 \mathrm{~m}^{2}$.

Bicarbonate loading. During sodium bicarbonate loading, with serum bicarbonate increasing from 17 to 23 $\mathrm{mmol} / \mathrm{L}$, the excretion of bicarbonate remained stable at $2 \%$ of the filtered load. The plasma $\mathrm{PCO}_{2}$ was $40 \mathrm{~mm} \mathrm{Hg}$, and the urinary $\mathrm{PCO}_{2}$ was $34 \mathrm{~mm} \mathrm{Hg}$ after bicarbonate loading. The (U-B) $\mathrm{PCO}_{2}$ during maximal alkalinization of the urine $(\mathrm{pH}=8.1)$ was -6 (normal $19 \pm 10)$.

Evaluation of the fractional excretion and reabsorption of carnitine showed a low fractional excretion of free $(1.26 \%)$ and esterified (3.32\%) carnitine when measured at basal endogenous free $(51 \mu \mathrm{mol} / \mathrm{L}$; Table 3$)$ and esterified $(14 \mu \mathrm{mol} / \mathrm{L})$ plasma carnitine concentrations. A high plasma threshold value, taking a value of $5 \%$ as the upper limit of normal for fractional free carnitine excretion, for free carnitine of $60 \mu \mathrm{mol} / \mathrm{L}$ (normal $46 \pm 7.0 \mu \mathrm{mol} / \mathrm{L}$ ) and normal tubular reabsorption of $6.40 \mu \mathrm{mol} / 100 \mathrm{~mL}$ glomerular filtrate (normal $7.2 \pm 0.4 \mu \mathrm{mol} / 100 \mathrm{~mL}$ ) were found (Table 3).

\section{DISCUSSION}

CPT I deficiency has been described in 10 patients (Table 3). The clinical presentation is characterized by recurrent episodes of hypoketotic hypoglycemia and relatively normal urinary organic acid excretion.

The CPT I activity measured in fibroblasts of our patient $(17 \%)$ was in the same range as the CPT I activity of other patients (10-23\%) reported in the literature. The age of onset of the initial symptoms in patients with CPT I deficiency varied between birth and 33 mo (Table 4). The most persistent clinical finding was hepatomegaly found at the time of a decompensation, which was found in all reported cases except in the patient of Tein $e t$ al.
(4). Blood glucose values during decompensation reportedly ranged between $0.55 \mathrm{mmol} / \mathrm{L}$ and normal. In followup, the patients often had a number of episodes of hypoglycemia and lethargy associated with intercurrent illness requiring hospitalization and parenteral glucose (4-6, 9-11). Bonnefont et al. (6) reported that these episodes decreased with age, which was also the case for our patient. There appeared to be no correlation between the age of onset or the severity of the clinical presentation and the degree of CPT I deficiency.

In our patient, hypoglycemia could only be found during the initial episode in the neonatal period. However, during the other nine episodes, glucose administration was followed by a quick recovery, probably reflecting low intracellular glucose concentration. One described patient with a CPT I deficiency never had documented periods of hypoglycemia, but died $11 \mathrm{~d}$ after she had been admitted to hospital in a coma (8).

The presence of a mild, nonspecific dicarboxylic aciduria in the acute episode was initially thought to suggest an intramitochondrial fatty acid oxidation defect. Increased dicarboxylic aciduria is generally not a feature of CPT I deficiency (9). Only once has a slightly increased urinary dicarboxylic acid profile been reported (Table 3; 10). Saturated $C_{12}$ dicarboxylic acid as the major component in the dicarboxylic acid profile has also been observed in a patient with hepatic CPT II deficiency shortly before the patient died (Pollitt R., personal communication).

Decreased concentrations of plasma carnitine and increases in the esterified fraction of carnitine have been associated with many defects in fatty acid metabolism, including the severe form of CPT II deficiency and deficiency of the carnitine-acylcarnitine translocase $(2,19)$. The exception to this rule are patients with a CPT I deficiency in whom the total plasma carnitine concentration is in the high-normal range (Table 4). The total and free plasma carnitine concentrations of our patient were 51 and $20 \mu \mathrm{mol} / \mathrm{L} 3 \mathrm{~d}$ after an acute episode, and after recuperation free carnitine was slightly increased (51-63 $\mu \mathrm{mol} / \mathrm{L})$. Renal carnitine handling in this patient was normal except for the elevated threshold of free carnitine reabsorption $(60 \mu \mathrm{mol} / \mathrm{L})$. The inability to form longchain acylcarnitines in CPT I deficiency and the knowledge that long-chain acylcarnitines are potent inhibitors of free carnitine transport $(20,21)$ explain an apparently

Table 2. Plasma and urine acid-base data before and after i.v. acid loading*

\begin{tabular}{|c|c|c|c|c|c|c|c|}
\hline & \multicolumn{3}{|c|}{ Plasma } & \multicolumn{4}{|c|}{ Urine } \\
\hline & $\mathrm{pH}$ & $\begin{array}{c}\mathrm{PCO}_{2} \\
(\mathrm{~mm} \mathrm{Hg})\end{array}$ & $\begin{array}{c}\mathrm{HCO}_{3}^{-} \\
(\mathrm{mmol} / \mathrm{L})\end{array}$ & $\mathrm{pH}$ & TA & $\begin{array}{c}\mathrm{NH}_{4}^{+} \\
\left(\mu \mathrm{Eq} \cdot \min ^{-1} \cdot 1.73 \mathrm{~m}^{-2}\right)\end{array}$ & $\begin{array}{c}\mathrm{H}^{+} \\
\left(\mu \mathrm{Eq} \cdot \min ^{-1} \cdot 1.73 \mathrm{~m}^{-2}\right)\end{array}$ \\
\hline Oral $\mathrm{HCO}_{3}{ }^{-}$suppletion & 7.38 & 38 & 22 & 7.0 & & & \\
\hline Spontaneous acidosis & 7.31 & 36 & 18 & 6.8 & 13 & 81 & 95 \\
\hline Acid loading & 7.25 & 37 & 16 & 4.7 & 70 & 108 & 179 \\
\hline $\begin{array}{l}\text { Values in normal controls after } \\
\text { prolonged acid loading } \dagger\end{array}$ & 7.38 & 30 & 17 & 5.2 & $45 \pm 2$ & $139 \pm 6$ & \\
\hline
\end{tabular}

${ }^{*} \mathrm{HCO}_{3}{ }^{-}$, bicarbonate; TA, titratable acid.

$\dagger$ Monnens et al. (29) mean $\pm \mathrm{SD}(n=14)$. 
BERGMAN ET $A L$.

Table 3. Renal handling of free and total carnitine

\begin{tabular}{|c|c|c|c|c|c|c|}
\hline & \multicolumn{3}{|c|}{ Free carnitine } & \multicolumn{3}{|c|}{ Total carnitine } \\
\hline & $\begin{array}{c}\mathrm{p}[\text { Carnitine }]^{*} \\
(\mu \mathrm{mol} / \mathrm{L})\end{array}$ & Reabsorption $\dagger$ & F.E. $\ddagger$ & $\begin{array}{c}\mathrm{p}[\text { Carnitine }]^{*} \\
(\mu \mathrm{mol} / \mathrm{L})\end{array}$ & Reabsorption $\dagger$ & F.E. \\
\hline \multirow[t]{2}{*}{ Endogenous carnitine } & 51 & 5.04 & 1.26 & 65 & 6.39 & 1.71 \\
\hline & 57 & 5.57 & 2.22 & 62 & 6.02 & 2.89 \\
\hline \multirow[t]{5}{*}{ L-Carnitine infusion§ } & 63 & 5.79 & 8.0 & 72 & 7.14 & 8.0 \\
\hline & 84 & 6.73 & 19.8 & 99 & 7.72 & 39.0 \\
\hline & 95 & 7.09 & 25.4 & 100 & 6.27 & 37.3 \\
\hline & 106 & 6.60 & 37.7 & 112 & 6.30 & 43.8 \\
\hline & 119 & 6.92 & 41.6 & 122 & 5.81 & 52.4 \\
\hline
\end{tabular}

* Plasma carnitine concentration.

$\dagger \mu \mathrm{mol} \cdot 100 \mathrm{~mL}$ glomerular filtrate ${ }^{-1}$.

‡ Fractional excretion \% $U_{\text {carnitine }} \times P_{\text {inulin }} / P_{\text {carnitine }} \times U_{\text {inulin }} \times 100$.

§ Infusion of L-carnitine $0.25 \mu \mathrm{mol} \cdot \mathrm{min}^{-1} \cdot \mathrm{kg}^{-1}$ for $200 \mathrm{~min}$.

higher renal threshold for free carnitine. In this view, high-normal-to-increased plasma carnitine values could be the first clue in distinguishing CPT I deficiency from other mitochondrial fatty acid oxidation disorders (9).

Although both palmitoyl-CoA (the accumulated product in CPT I deficiency) and palmitoylcarnitine (the accumulated product in CPT II deficiency) have been implicated in damaging the in vitro cardiac models $(22,23)$, only palmitoyl-CoA can leave the liver cell and thereby damage the cardiac muscle; palmitoylcarnitine is unable to leave the liver cell. This is an argument for the absence of a myocardial involvement in CPT I deficiency. Another hypothesis for the lack of cardiac involvement in the classic "hepatic" form of CPT I deficiency would be the presence of tissue-specific isoforms of the CPT I enzyme. The classic hepatic form of CPT I deficiency is expressed in cultured skin fibroblasts and liver but not in muscle (4). Data obtained in rat and mouse suggest the presence of distinct CPT I isoforms in the liver, skeletal muscle, and heart (24).

RTA in association with defects of fatty acid oxidation has rarely been reported. Detailed information about the renal function in CPT I deficiency has been reported only in one case in which distal tubular acidosis was suggested based on a decreased (U-B) $\mathrm{PCO}_{2}(10)$. The persistence of the metabolic acidosis in our patient led us to perform extensive renal function tests.

RTA is a condition characterized by tubular insuffciency either in the renal reabsorption of bicarbonate (proximal RTA), the excretion of hydrogen ion (dRTA), or both (25).

In our patient, urinary $\mathrm{H}^{+}$excretion was insufficient to maintain the blood $\mathrm{pH}$ within the normal range, resulting in acidosis after discontinuation of the daily bicarbonate supplementation. The urinary $\mathrm{pH}$ was insufficiently lowered in relation to the low serum bicarbonate. During bicarbonate loading, urinary bicarbonate excretion at low and normal plasma bicarbonate values was less than $5 \%$, suggesting the diagnosis of dRTA.

During acid loading, urinary $\mathrm{pH}$ decreased normally and total acid excretion increased. Having taken into account the chronic acid load, urinary $\mathrm{NH}_{4}{ }^{+}$excretion remained relatively low (Table 2). The excretion of acid urine excludes the diagnosis of classic dRTA.

The measurement of the urinary $\mathrm{PCO}_{2}$ in alkaline urine is a different method for evaluating $\mathrm{H}^{+}$secretion by the distal nephron (26). When the distal nephron is flooded with bicarbonate-containing fluid, hydrogen ions that are excreted into the distal nephron and collecting duct neutralize bicarbonate, thereby forming carbonic acid $\left(\mathrm{H}_{2} \mathrm{CO}_{3}\right)$. The dissociation of $\mathrm{H}_{2} \mathrm{CO}_{3}$ into $\mathrm{H}_{2} \mathrm{O}$ and $\mathrm{CO}_{2}$ progresses slowly, because there is no carbonic anhydrase present in the lumen of the distal nephron. The diffusion of $\mathrm{CO}_{2}$ out of the tubular fluid being restricted, the (U-B) $\mathrm{PCO}_{2}$ gradient reflects distal tubular $\mathrm{H}^{+}$secretion (27).

The low (U-B) $\mathrm{PCO}_{2}$ found in this patient $(-6)$ is in concordance with the findings of Falik-Borenstein et al. (10) and reflects a dysfunction in tubular $\mathrm{H}^{+}$secretion. In our opinion, this condition could best be described as $\left(\mathrm{H}^{+}\right.$secretion) rate-dependent dRTA (28).

The occurrence of such a disorder of acid-base homeostasis in at least two patients with CPT I deficiency suggests a relationship between the two phenomena. It is tempting to assume a role for long-chain acylcarnitines in this respect. These substances may influence the renal handling of free carnitine (9). It is not known whether the primarily proximal renal tubular reabsorption of free carnitine interferes with the proximal tubular ammonium production and hence acid excretion. However, this does not explain the defect in distal tubular hydrogen excretion. Another possible "nonspecific" mechanism to be considered for the rate-dependent dRTA would be a defect in energy metabolism in the kidney due to deficiency of the renal CPT I isoform, because fatty acid oxidation is thought to be an important source of energy in the kidney. In the CPT I deficiency case described by Falik-Borenstein et al. (10), the administration of MCT to a CPT I-deficient patient led to the complete resolution of the RTA.

Many additional in vivo and in vitro experiments will be needed, such as cautious administration of small amounts of long-chain acylcarnitines under close medical supervision to CPT I-deficient patients or preferably an in vitro 
Table 4. Clinical and biochemical presentation of patients with CPT I deficiency*

\begin{tabular}{|c|c|c|c|c|c|c|c|}
\hline Author & Sex & $\begin{array}{l}\text { Age of } \\
\text { onset }\end{array}$ & Clinical findings & $\begin{array}{l}\text { Plasma } \\
\text { glucose } \\
(\mathrm{mmol} / \mathrm{L}) \dagger\end{array}$ & $\begin{array}{l}\text { Plasma } \\
\text { carnitine } \\
(\mu \mathrm{mol} / \mathrm{L})\end{array}$ & $\begin{array}{l}\text { Organic } \\
\text { aciduria }\end{array}$ & Course \\
\hline $\begin{array}{l}\text { Bougnères et al. } \\
\qquad(3-5) \ddagger\end{array}$ & $\mathrm{F}$ & $8 \mathrm{mo}$ & $\begin{array}{l}\text { Seizures, coma, } \\
\text { hepatomegaly }\end{array}$ & 1.2 & ND & Normal & $\begin{array}{l}11 \text { y normal growth and } \\
\text { development }\end{array}$ \\
\hline Tein et al. $(4,5) \ddagger$ & M & $13 \mathrm{mo}$ & $\begin{array}{l}\text { Hepatic encephalopathy, } \\
\text { coma after infection, } \\
\text { right-side hemiplegia }\end{array}$ & Hypoglycemia & $\begin{array}{r}\text { Total } 55 \\
\text { free } 45\end{array}$ & Normal & $\begin{array}{l}15 \text { mo seizures, } 16 \text { mo } \\
\text { hypoglycemic encephalopathy, } \\
5 \text { y seizures, } 11 \text { y normal } \\
\text { growth, delayed cognitive } \\
\text { function }\end{array}$ \\
\hline $\begin{array}{l}\text { Bonnefont et al. } \\
\quad(6)\end{array}$ & $\mathbf{F}$ & $2 \mathrm{~d}$ & Respiratory arrest & $5 \mathrm{mg} / \mathrm{dL}$ & $\begin{array}{r}\text { Total } 64 \\
\text { free } 63\end{array}$ & ND & $\begin{array}{l}10 \text { mo hepatosplenomegaly, } \\
11 \text { mo coma and transient } \\
\text { renal tubular acidosis, } 14 \text { mo } \\
\text { lethargy, seizures, hemiparesis, } \\
\text { recurrent episode of } \\
\text { hypoglycemia }\end{array}$ \\
\hline Gray et al. (7) & M & At birth & Jitteriness & 1.0 & ND & ND & $\begin{array}{l}14 \text { mo hypoglycemia, } \\
\text { hepatomegaly, } 22 \text { mo normal } \\
\text { development, anemia }\end{array}$ \\
\hline $\begin{array}{l}\text { Vianey-Saban } \\
\text { et al. }(8)\end{array}$ & $\mathrm{F}$ & $33 \mathrm{mo}$ & $\begin{array}{l}\text { Coma, hepatomegaly after } \\
\text { infection }\end{array}$ & Normal & $\begin{array}{r}\text { Total } 290 \\
\text { free } 231\end{array}$ & Normal & 33 mo death, multiorgan failure \\
\hline Stanley et al. (9) & M & $12 \mathrm{mo}$ & $\begin{array}{l}\text { Hypoglycemic seizures, } \\
\text { amoebic dysentery, } \\
\text { hepatomegaly }\end{array}$ & 0.94 & $\begin{array}{r}\text { Total } 250 \\
\text { free } 161\end{array}$ & $\begin{array}{l}\text { Present, not } \\
\text { abnormally } \\
\text { elevated }\end{array}$ & $\begin{array}{l}\text { Recurrent episodes of } \\
\text { hypoglycemia, } 4.6 \text { y normal } \\
\text { development, no impaired renal } \\
\text { function }\end{array}$ \\
\hline $\begin{array}{l}\text { Falik-Borenstein } \\
\text { et al. }(10)\end{array}$ & $\mathrm{F}$ & $14 \mathrm{mo}$ & $\begin{array}{l}\text { Coma, respiratory arrest } \\
\text { after infection, } \\
\text { hepatomegaly }\end{array}$ & 0.55 & Normal & $\begin{array}{l}\text { Slightly } \\
\text { increased }\end{array}$ & $\begin{array}{l}17 \text { and } 20 \text { mo respiratory arrest, } \\
\text { RTA }\end{array}$ \\
\hline \multirow[t]{3}{*}{$\begin{array}{l}\text { Haworth et al. } \\
\text { (11) }\end{array}$} & M & $14 \mathrm{mo}$ & $\begin{array}{l}\text { Hypertonic dehydration, } \\
\text { hepatomegaly }\end{array}$ & 0.9 & $\begin{array}{r}\text { Total } 67 \\
\text { free } 67\end{array}$ & Normal & $\begin{array}{l}23 \text { mo hypoglycemia, seizures, } \\
7 \text { y hypoglycemia, coma, } 12 \text { y } \\
\text { seizures, delayed mental } \\
\text { development }\end{array}$ \\
\hline & $\mathrm{F}$ & $8 \mathrm{mo}$ & Seizures, hepatomegaly & 2.2 & $\begin{array}{l}\text { Total } 107 \\
\text { free } 77\end{array}$ & Normal & $\begin{array}{l}3 \text { mo hypoketotic hypoglycemia, } \\
26 \text { mo stuporous, } \\
\text { hypoglycemia, recurrent } \\
\text { hypoglycemia, } 4 \text { y IQ } 91\end{array}$ \\
\hline & $\mathbf{F}$ & $18 \mathrm{mo}$ & Hypoketotic hypoglycemia & 2.0 & $\begin{array}{r}\text { Total } 69 ; \\
\text { free } 58\end{array}$ & Normal & $\begin{array}{l}\text { Recurrent hypoglycemia, } \\
\text { decreased consciousness, } \\
\text { hepatomegaly, } 42 \text { mo } \\
\text { development low-normal range }\end{array}$ \\
\hline Present case & $\mathrm{F}$ & $3 d$ & $\begin{array}{l}\text { Lethargy, respiratory } \\
\text { arrest, hepatomegaly }\end{array}$ & 1.5 & $\begin{array}{r}\text { Total } 76 \\
\text { free } 63\end{array}$ & $\begin{array}{l}\text { Dicarboxylic } \\
\text { aciduria }\end{array}$ & $\begin{array}{l}\text { Episodes of Reye-like syndrome, } \\
\text { tubular acidosis, } 3 \text { y normal } \\
\text { mental and motor development }\end{array}$ \\
\hline
\end{tabular}

* F, female; $M$, male; ND, not determined or not reported.

$\dagger$ During decompensation.

\$ Bougnères’ patient was also described by Refs. 4 and 5 .

model to further explore the precise mechanism of the rate-dependent dRTA in CPT I-deficient patients.

\section{REFERENCES}

1. Murthy MRS, Pande SV 1987 Malonyl-CoA binding site and the overt carnitine on palmitoyltransferase activity reside on the opposite sides of the outer mitochondrial membrane. Proc Natl Acad Sci USA 13:663-668

2. Pande SV, Brivet M, Slama A, Demaugre F, Aufrant C, Saudubray J 1993 Carnitine-acylcarnitine translocase deficiency with severe hypoglycemia and auriculoventricular block. Translocase assay in permeabilized fibroblasts. J Clin Invest 91:1247-1252

3. Bougnères PF, Saudubray JM, Marsac C, Bernard O, Odi vre M, Girard J 1981 Fasting hypoglycemia resulting from hepatic carnitine palmitoyl transferase deficiency. J Pediatr 98:742-746

4. Tein I, Demaugre F, Bonnefont JP, Saudubray JM 1989 Normal muscle CPT I and CPT II activities in hepatic presentation patients with CPT I deficiency in fibroblasts. Tissue specific isoforms of CPT I? J Neurol Sci 92:229-245

5. Demaugre F, Bonnefont JP, Mitchell G, Nguyen-Hoang N, Pelet A, Rimoldi M, Di Donato S, Saudubray JM 1988 Hepatic and muscular presentations of carnitine palmitoyl transferase deficiency: two distinct entities. Pediatr Res 24:308-311

6. Bonnefont JP, Haas R, Wolff J, Thuy LP, Buchta R, Carroll JE, Saudubray
JM, Demaugre F, Nyhan WL 1989 Deficiency of carnitine palmitoyltransferase I. J Child Neurol 4:198-203

7. Gray RGF, Green A, Kelly DA 1991 A case of carnitine palmitoyl-transferase I deficiency. 2nd International Symposium on Clinical, Biochemical, and Molecular Aspects of Fatty Acid Oxidation, Philadelphia

8. Vianey-Saban C, Mousson B, Bertrand C, Stamm D, Dumoulin R, Zabot MT, Divry P, Floret D, Mathieu M 1993 Carnitine palmitoyl transferase I deficiency presenting as a Reye-like syndrome without hypoglycaemia. Eur J Pediatr 152:334-338

9. Stanley CA, Sunaryo F, Hale DE, Bonnefont JP, Demaugre F, Saudubray JM 1992 Elevated plasma carnitine in the hepatic form of carnitine palmitoyltransferase-1 deficiency. J Inherit Metab Dis 15:785-789

10. Falik-Borenstein ZC, Jordan SC, Saudubray JM, Brivet M, Demaugre F, Edmond J, Cederbaum SD 1992 Brief report: renal tubular acidosis in carnitine palmitoyl transferase type 1 deficiency. N Engl J Med 327:24-27

11. Haworth JC, Demaugre F, Booth FA, Dilling LA, Moroz SP, Seshia SS Seargeant LE, Coates PM 1992 Atypical features of the hepatic form of carnitine palmitoyltransferase deficiency in a Hutterite family. J Pediatr 121:553-557

12. Duran M, Bruinvis L, Ketting D, de Klerck JBC, Wadman SK 1988 Plasma cis-4-decenoic acid, a characteristic metabolite in medium-chain acylcoenzyme A dehydrogenase deficiency. Clin Chem 34:548-551

13. Duran M, Ketting D, Bruinvis L, Dorland L, Wadman SK, Bakkeren JAJM 1987 Urinary excretion of 2-methyl-2,3-butanediol and 2,3-pentadiol in pa- 
tients with disorders of propionate and methylmalonate metabolism. Clin Chim Acta 165:197-204

14. Pearson D, Tubbs P, Chase J 1974 Carnitine and acylcarnitines. Methods Enzymol Anal 4:1758-1771

15. Bertrand C, Dumoulin R, Vianey-Saban C, Divry P, Mathieu M 1992 Purification of electron transfer flavoprotein from pig liver mitochondria and its application to the diagnosis of deficiencies of acyl-CoA dehydrogenases in human fibroblasts. Clin Chim Acta 210:75-91

16. Davidson MD, Sackner MA 1963 Simplification of the anthrone method for determination of inulin in clearance studies. J Lab Clin Med 62:351-354

17. Loney LC, Norling LL, Robson AM 1982 The use of arginine hydrochloride infusion to assess urinary acidification. J Pediatr 100:95-98

18. Engel AG, Rebouche CJ, Wilson DM, Glasgow AM, Romsche CA, Crose RP 1981 Primary systemic carnitine deficiency: II. Renal handling of carnitine Neurology 31:819-825

19. Demaugre F, Bonnefont JP, Collona M, Cepanec C, Leroux JP, Saudubray JM 1991 A form of carnitine palmitoyltransferase II deficiency with hepatomuscular symptoms and sudden death. J Clin Invest 87:859-864

20. Mølstad P, Bøhmer T, Eiklid K 1977 Specificity and characteristics of the carnitine transport in human heart cells (CCL 27) in culture. Biochim Biophys Acta 471:296-304

21. Stanley CA, Deleeuw S, Coates PM, Vianey-Liaud C, Divry P, Bonnefont JP Saudubray JM, Haymond M, Trefz FK, Breningstall GN 1991b Chronic myopathy or acute coma in children with a defect in carnitine uptake. Ann Neurol 30:709-716
22. Corr PB, Creer MH, Yamada KA, Saffits JE, Sobel BE 1989 Prophylaxis of early ventricular fibrillation by inhibition of acylcarnitine accumulation. $J$ Clin Invest 83:927-936

23. Mak T, Kramer JH, Weglicki WB 1986 Potentiation of free radical-induced lipid peroxidative injury to sarcolemmal membranes by lipid amphiphiles. J Biol Chem 261:1153-1157

24. McGarry JD, Woeltjes KF, Schroeder JG, Cox WF, Foster DW 1990 Carnitine palmitoyltransferase-structure/function/regulatory relationships. In: Tanaka K, Coates PM (eds) Fatty Oxidation: Clinical, Biochemical and Molecular Aspects. Alan R Liss, New York, pp 193-208

25. Donckerwolcke RA 1983 Diagnosis and treatment of renal tubular disorders in children. Pediatr Clin North Am 29:895-906

26. Halperin ML, Goldstein MB, Haig A, Johnson MD, Stinebaugh BJ 1974 Studies on the pathogenesis of type 1 (distal) renal tubular acidosis as revealed by the urinary $\mathrm{pCO}_{2}$ tensions. J Clin Invest 53:669-677

27. Donckerwolcke RA, Valk C, van Wijngaarden-Penterman MJG, van Stekelenburg GJ 1983 The diagnostic value of urine to blood carbon dioxide tension gradient for the assessment of distal tubular hydrogen secretion in pediatric patients with renal tubular disorders. Clin Nephrol 19:254-258

28. Strife CF, Clardy CW, Varade WS, Prada AL, Waldo FB 1993 Urine-to-blood carbon dioxide tension gradient and maximal depression of urinary $\mathrm{pH}$ to distinguish rate-dependent from classic distal renal tubular acidosis in children. J Pediatr 122:60-65

29. Monnens L, Schretlen E, van Munster P 1973 The renal excretion of hydrogen ions in infants and children. Nephron 12:29-43

\section{Erratum}

In the article "Involvement of Erythrocyte Calpain in Glycine- and Carnitine-Treated Isovaleric Acidemia" (Pediatric Research 36:182-186, 1994), one of the authors' names was misspelled. The sixth author should have been "Roberta De Tullio." We regret the error. 